\section{Obraz jako szibbolet. Wokół Pierścieni Saturna W. G. Sebalda}

Radosław Filip Muniak

TEKSTY DRUGIE 2018, NR 2, S. 316-334

DOI: $10.18318 /$ td.2018.2.20

\section{Prof.Annie Zeidler-Janiszewskiej}

Relacja do znaczenia lub do przedmiotu była zawieszona, zneutralizowana, wtrącona w nawias: przeciwieństwo, można by tak powiedzieć, fenomenologicznego „epoche”, które strzeże przede wszystkim znaczenia.'

\section{Kawałek nieba}

Wszystko zaczyna się od okna.

Rok po rozpoczęciu pieszej wędrówki po wschodnioangielskim hrabstwie Suffolk główny bohater Pierścieni Saturna zostaje odwieziony do szpitala w Norwich, gdzie na ósmym piętrze, w stanie kompletnego wyczerpania patrzy w okno.

Faktycznie z mego łóżka nie widać było ze świata nic prócz bezbarwnego kawałka nieba w ramie okna. ${ }^{2}$

1 J. Derrida Szibbolet dla Paula Celana, przeł. A Dziadek, Bytom 2000, s. 26.

2

W.G. Sebald Pierścienie Saturna. Angielska pielgrzymka, przeł. M. Łukasiewicz, Warszawa 2009, s. 8.

\author{
Radosław Filip \\ Muniak - doktor \\ nauk humanistycz- \\ nych, wieloletni wy- \\ kładowca akademicki \\ (Uniwersytetu SWPS) \\ i buddysta. Autor \\ książek Efekt lalki, \\ Kulturowe wymiary \\ ludobójstwa i licznych \\ tekstów naukowych \\ z dziedziny estetyki, \\ filozofii obrazu \\ i kultury. Miłośnik \\ nieoczywistości, \\ tatuaży i pisania po \\ nocach, od dwóch lat \\ bezdomny w nieusta- \\ jącej podróży.
}


Pytanie, czy patrzy „w okno” czy „przez okno”? Czy widzi kawałek nieba przez ramę okna czy samą ramę, która przedstawia kawałek nieba? Czy między tymi dwoma widzeniami jest jakaś różnica? Jeżeli tak, to na czym ona polega? Dylemat ten wpisuje się w immanentną dla problematyki reprezentacji dychotomię - autoreferencyjność czy mimesis? Innymi słowy, czy obraz jest rodzajem glosy (odbicia) dla rzeczywistości, czy sam w sobie ją ustanawia?

Według XVII-wiecznej definicji Antoine’a Furetière’a obraz (tableau) w architekturze oznacza także "otwory drzwiowe, okna i otwory okienne, otwory w murze pozwalające na doświetlenie wnętrza bądź wejście do pokoju”3.

Obraz jako powierzchnia, na którą naniesione jest malowidło, a także obraz jako otwór wykonany w ścianie tworzą dwa znaczenia tego samego słowa, nie wykluczające się wzajemnie, lecz uzupełniające. ${ }^{4}$

W 2000 roku Jeff Wall tworzy tryptyk Blind Window, poprzez który (jak Sebaldowski narrator przez okno) wyraża swój stosunek do obrazu fotograficznego - krytykuje tradycyjną koncepcję obrazu jako okna, przez które możemy zobaczyć świat. Pierwsze zdjęcie tryptyku ukazuje okno, które jest zasłonięte od wewnątrz (dodatkowo, zagrodzone od zewnątrz drewnianą belką), przez co w świetle dziennym staje się refleksyjne (sic!) jak lustro. Drugie zdjęcie przedstawia okno widziane z perspektywy pomieszczania, gdzie szkło zostało albo zakryte, albo zastąpione deskami. Natomiast trzecie Blind Window ukazuje okno z zieloną ramą, którego szyba pomalowana jest na czarno. Każde okno jest zatem zasłonięte, zabarykadowane, ślepe, co kompletnie niweczy jego funkcję. Wall sugeruje, że obrazem może być samo okno, które nie stanowi bramy, przez którą przechodzimy (wyglądamy), tylko istnieje samo dla siebie. Ślepe okno czyni - poprzez pewne metaodniesienie tematyczne widzialnym, to co powinno być niewidzialne. Zdjęcia Walla wystawiane są w formie podświetlanych ekranów. Artysta poprzez przedstawienie zakrytych okien w formie transparencji chce wprowadzić w ideę przejrzystości

3 W języku polskim odpowiednikiem tego są ościeże. Ciekawą zabawą słowną może być, w kontekście widzenia ramy okiennej jako obrazu lub ramy jako otworu, przez który oglądamy świat, polskie sformułowanie „otworzyć okno na oścież", gdzie rzeczownikiem, któremu podlega czasownik, jest sama oścież, a nie - jak wydawałoby się logiczne - zewnętrze (otworzyć okno na zewnątrz).

4 V.I. Stoichita Ustanowienie obrazu. Metamalarstwo u progu ery nowoczesnej, przeł. K. Thiel-Jańczuk, Gdańsk 2011, s. 9. 
element zaciemnienia. Każe się nam zastanowić nad ideą przejrzystości w ogóle, tym samym tradycyjnym pojęciem obrazu. Czy szyba rzeczywiście ukazuje rzeczywistość sauté, bez interwencji? ${ }^{5}$ Przez prosty zabieg zasłonięcia okna artysta czyni z niego obiekt, „na który” patrzymy raczej, niż „przez który” patrzymy. Okno staje się referentem dla samego siebie, nie dla czegoś poza nim. W tym sensie obraz istnieje jakby w naskórku widzialności i niewidzialności ${ }^{6}$. Wall ukazuje drugą stronę lustra (obrazu), na jego odwrocie, miejsce, w którym według mnie na początku powieści znajduje się narrator Pierścieni Saturna i z którego patrzy przez okno na rzeczywistość, jakby „z wnętrza obrazu".

Od początku wynalezienia fotografii używano do jej opisu metafory okna czy szyby, przez którą odkrywamy i patrzymy na rzeczywistość, nie musząc bezpośrednio w niej uczestniczyć. Oczywiście metaforę okna stosowano również do opisu malarstwa ${ }^{7}$, ale to właśnie pierwsze fotografie (jako metafory samego medium) przedstawiały okna ${ }^{8}$. W tym sensie fotografia (jako obraz „najbliższy” rzeczywistości) pełni funkcję transferu, za sprawą którego (jak przez okno) możliwe jest oglądanie tego, co znajduje się "na zewnątrz",

5 Podobne dylematy związane z ideą przejrzystości reprezentacji podkreśla Josef Sudek w serii zdjęć The Window of MyStudio (1940-1954) czy na poziomie bardziej konceptualnym Paul Strand poprzez swoje sławne zdjęcie Blind (1916) niewidomej kobiety z napisem „niewidoma” na szyi.

6 "Modernistyczna koncepcja malarstwa polegała na podkreśleniu roli powierzchni obrazu jako powierzchni, chciała sprzeciwić się teorii iluzjonistycznej, według której obraz w pewnym sensie jest jedynie efektem powierzchni. Myślę, że można patrzeć na fotografię w podobny sposób, ale z racji tego, że nie jest ona malarstwem, są pewne różnice. Gdy staramy się odbierać powierzchnię zdjęcia w podobny sposób jak malarstwo, stwierdzamy, że powierzchnia jest tak naprawdę niewidzialna. Nazywam to radykalną niewidzialnością powierzchni. Aczkolwiek nasze poczucie modernizmu w fotografii związane jest z relacją pomiędzy powierzchnią a iluzją. Powierzchnia, którą zajmuje się fotografia jest niewidzialna". Zob. J. Wall Interview by F. Tietjen, przekł. wł., w: „Camera Austria International” 2003 No. 82, s. 14.

7 Już Alberti w swoim traktacie O malarstwie porównuje stworzenie obrazu do "Otworzenia okna". Zob. L.B. Alberti O malarstwie, przeł. L. Winniczuk, Wrocław 1963,

8 Jedno z pierwszych zdjęć w ogóle zrobiono z okna, mowa oczywiście o sławnej heliografii Josepha Niépce'a Widok z okna w Le Gras (1826). William Henry Fox Talbot, jeden z niezależnych wynalazców fotografii, skupiał uwagę nie tyle na zdjęciu jako „przezroczystej szybie”, za którą odkrywamy rzeczywistość, ile raczej, a przynajmniej równorzędnie, na szybie jako metaforze samego medium fotograficznego. Punktem wyjścia stała się seria obrazów okien zrobionych camera obscura (1835), które ukazywały nie tyle rzeczywistość poza, ile właśnie same były obiektem zainteresowania i refleksji. Zob. J.L. Schaaf The Photographic Art of William Henry Fox Talbot, Princeton University Press 2000, s. 34-35. 
w sensie - poza naszą podmiotowością? . Dlatego słownemu opisowi doświadczenia bohatera powieści Sebalda towarzyszy zdjęcie, które ukazuje prostokątny kształt wyłaniający się z absolutnej czerni, uchwycony pod kątem, co powoduje, że wygląda jak oparte o ścianę płótno malarskie przedstawiające chmury i niebo. Skojarzenia z obrazem René Magritte'a Kondycja ludzka (1933) nasuwają się same: przed oknem stoi sztaluga z obrazem, okno wychodzi na polanę, którą przecina ścieżka; w tle widać błękitne niebo ukoronowane białymi chmurkami, samotne drzewo i krzaki. Obraz na sztaludze jednocześnie zasłania krajobraz i dokładnie go odwzorowuje. Magritte każe się zastanowić, czy krajobraz, który jest za oknem, istnieje jako faktyczny krajobraz czy jedynie jako obraz krajobrazu? Czy bohater Pierścieni Saturna widzi w szpitalu obraz rzeczywistości, czy rzeczywistość obrazu (okno)? Magritte wydaje się negować możliwość widzenia bez obrazowania, co więcej, sugeruje, że na tym polega kondycja ludzka. Obraz (jako przedmiot materialny) unieruchamia doświadczenie widzenia, czyni je sztucznym; ukrywa prawdziwą rzeczywistość, ale czy można inaczej?

Sebaldowskie okno odgrodzone jest od rzeczywistości siatką (kratą, ang. grid). Według Rosalind Krauss figura siatki jest typowa dla sztuki awangardowej, gdyż charakteryzuje ją nieprzepuszczalność języka:

Wzór siatki sprzyja temu założonemu milczeniu, wzmacniając je wręcz do świadomej odmowy mówienia. Jej kompletny bezruch, brak hierarchicznej struktury, środka i modyfikacji, uwydatnia nie tylko anty-referencyjny charakter, ale - co najważniejsze - niepodatność na narrację. Struktura przecinających się linii, odporna na wpływ czasu i przypadku, broni językowi wstępu w domenę sztuk wizualnych, czego oczywistym rezultatem jest milczenie. ${ }^{10}$

To milczenie wynika z wyłączenia przyrody, która zostaje skurczona do rozmiarów przedmiotu czysto kulturowego.

9 Charles Peirce, wśród trzech wyróżnionych przez siebie typów znaków, fotografii przypisał przede wszystkim charakter indeksowy i ikoniczny, a więc kładąc silny akcent na jej referencyjność. Filozof nazwał indeksowym taki proces semiozy (semiosis), w którym element znaczący jest związany ze swoim referentem nie przez społeczną konwencję (symbol), niekoniecznie również przez jakieś podobieństwo (znak ikoniczny), ale przez faktyczną styczność (szyba) bądź powiązanie w świecie.

10 R. Krauss Oryginalność awangardy, przeł. M. Sugiera w: Postmodernizm. Antologia tekstów, red. R. Nycz, Kraków 1997, s. 406-407. 
Do odkrycia krajobrazu potrzeba jednostki przeżywającej estetycznie jakiś fragment przyrody, co oznacza, że natura staje się krajobrazem, gdy uobecnia się w spojrzeniu obserwatora przeżywającego ją i odczuwającego w sposób estetyczny. ${ }^{11}$

Natura oglądana przez symboliczną siatkę lub okno (a inaczej nie można) staje się krajobrazem, czyli widzeniem natury, które łączy się ze szczególnym rodzajem wyobcowania z niej - spojrzenia z zewnątrz. Staje się „spojrzeniem fotograficznym", jak ujął to Hans Belting ${ }^{12}$. Według niego kontemplowanie natury musi zakładać dystans. Pejzaż jest obrazem, czyli czymś obramowanym (ograniczonym), zatrzymanym, ale też - idąc tropem teorii Krauss niemożliwym do opisania. Georg Simmel z kolei uważał, że krajobraz jest „tworem duchowym”. Natura sama w sobie nie jest jeszcze krajobrazem, gdyż jej istotą jest „bezgraniczna jedność”. Aby zaistniał krajobraz, tzn. abyśmy mogli oglądać naturę jako obraz, musi nastąpić proces rozczłonkowania „ujęty w ramy chwilowego lub stałego pola widzenia"13. Proces ten nie jest jednak czymś stałym, owe ramy, w które ujmujemy naturę, by ją oglądać, wciąż się rozmywają, ponieważ są ustanowione przez człowieka, tym samym zmienne i subiektywne. Nie sposób nigdy uchwycić tego samego obrazu natury, podobnie jak wrócić do tego samego miejsca (szibbolet).

Krajobraz powstaje wtedy, gdy życie pulsujące w oglądzie i odczuciu odrywa się od jednolitego bytu natury, wyodrębnia i na nowej płaszczyźnie samo z siebie znowu otwiera się na owo wszechżycie, gotowe w swoich określonych granicach zawsze być bezgraniczne. ${ }^{14}$

Krauss sprowadza funkcję powierzchni pokrytej siatką do obrazu absolutnego początku.

Przypuszczalnie ze względu na ten sens początku, nowego startu czy zaczynania od zera, wielu artystów wybierało figurę siatki jako swoje

B. Frydryczak Natura jako medium obrazów, „Przegląd Kulturoznawczy” 2009 nr 1 (5), s. 35.

Zob. H. Belting Antropologia obrazu, przeł. M. Bryl, Kraków 2007.

Zob. G. Simmel Filozofia krajobrazu w: tegoż Most i drzwi. Wybór esejów, przeł. M. Łukasiewicz, Warszawa 2006.

G. Simmel Filozofia krajobrazu, s. 295. 
medium, a każdy w taki sposób, jakby właśnie ją był odkrył, jakby zdejmując kolejne warstwy reprezentacji dotarł był wreszcie do zredukowanego schematu, tej graficznej podstawy, gdzie jego własny początek i odkrycie go stają się jednym aktem oryginalności. ${ }^{15}$

Dlatego „osiatkowane" okno stanowi pierwszy, a zarazem, paradoksalnie, ostatni obraz powieści Sebalda. Ostatni, gdyż zgodnie z chronologią narracji scena w szpitalu stanowi efekt wędrówek bohatera, czyli zakończenie tego, co jako czytelnicy/widzowie, dopiero będziemy czytać/oglądać. W tym sensie „kawałek nieba”, który widzi przez okno bohater (i my jako czytelnicy), jest zarówno zapowiedzą początku doświadczenia bohatera $\mathrm{w}$ „ angielskiej pielgrzymce”, jak i obrazem (ramą) jego końca. Narrator ogląda świat „z wnętrza obrazu", ale także przekształca go „tylko w obraz”, w okno, za którym tak naprawdę nic nie ma, gdyż już się skończyło.

Dopiero o świcie, gdy nocne siostry skończyły dyżur, zorientowałem się znowu, gdzie jestem. Zacząłem czuć własne ciało, drętwą stopę, bolące miejsce na plecach, rejestrowałem szczęk talerzy, jakim na korytarzu zaczynał się szpitalny dzień, a kiedy pierwszy brzask rozświetlił przestworze, zobaczyłem smugę kondensacyjną, biegnącą, jak się zdawało, własną mocą w poprzek obramowanego oknem kawałka nieba. Uznałem wtedy tę białą smugę za dobry znak, ale teraz, patrząc wstecz, lękam się, że była raczej początkiem rysy, która odtąd idzie przez moje życie. ${ }^{16}$

\section{Dwu-widzenie}

Narrator Pierścieni Saturna po kilku dniach leżenia w łóżku zaczyna obawiać się, że za oknem, które widzi, nic nie ma, że rzeczywistość została wymazana, sprowadzona tylko do tego jednego wycinka; że została doszczętnie „uobrazowiona”:

Nawiedzające mnie już kilkakrotnie za dnia pragnienie, by wyjrzeć przez dziwacznie osłonięte czarną siatką okno szpitalne i upewnić się co do, jak się obawiałem, na zawsze zanikłej rzeczywistości, stało się w porze zmierzchu tak silne, że kiedy już jakimś sposobem, po trosze na brzuchu, po trosze bokiem, udało mi się zsunąć przez krawędź łóżka na podłogę

15 R. Krauss Oryginalność awangardy, s. 407-408. 
i doczołgać do ściany, to pomimo towarzyszącego temu bólu dźwignąłem się na nogi, przytrzymując się mozolnie parapetu. W kurczowej pozycji istoty, która po raz pierwszy podniosła się z równej ziemi, stałem potem oparty o szybę i mimo woli przyszła mi na myśl scena, kiedy biedny Gregor, drżącymi nóżkami wczepiony w oparcie krzesła, wygląda ze swego gabinetu, z niejasnym, jak czytamy, wspomnieniem, że patrzenie przez okno zawsze działało na niego wyzwalająco. ${ }^{17}$

Porównuje się do insekta z Przemiany Kafki. Poza konotacjami interpretacyjnymi związanymi ze znaczeniem przemiany Gregora Samsy jako symbolu wyobcowania, co niewątpliwie wpisuje się także w sytuację narratora Sebalda, warto przyjrzeć się szczególnie jednemu fragmentowi opowiadania Kafki - kluczowej dla rozwoju akcji scenie wynoszenia przez matkę i siostrę Gregora mebli z jego pokoju. Siostra w porywie dobroduszności chce zrobić Gregorowi więcej miejsca do chodzenia i zaczyna wynosić z pokoju wszystkie jego rzeczy. Nie zakłada jednak, że jej brat wcale tego nie chce: „musiał sobie otwarcie powiedzieć, że długo tego wszystkiego nie wytrzyma. One ogołacały jego pokój; zabierały wszystko, co mu było drogie"18. Podobnie jak bohater powieści Sebalda, który leży w szpitalu ogołocony z sił i w pewnym sensie wspomnień (przemieniony), Gregor chcąc uchronić cokolwiek ze swojego poprzedniego życia, rzuca się na obraz wiszący na ścianie.

co najpierw powinien ratować, nagle wzrok jego padł na obraz damy przystrojonej w futro, wiszący na pustej już zresztą ścianie. Szybko podpełznął w górę i przycisnął się do szkła, które go zatrzymało chłodząc przyjemnie jego gorący brzuch. Przynajmniej tego obrazu, który Gregor całkiem zakrywał, nikt z pewnością nie zabierze. ${ }^{19}$

Dlaczego bohater opowiadania Kafki wybiera akurat obraz i przysłania go własnym ciałem, jakby chciał ukryć go w sobie? Pragnie ustrzeć go i samego siebie przed zapomnieniem, poprzez wprost fizyczne zjednanie się z nim, ponieważ nic już poza obrazem mu nie zostało. Gest, który jak wiadomo, prowadzi do strasznych konsekwencji przy użyciu jabłka i ostatecznie

17 Tamże, s. 9.

18 F. Kafka Przemiana, przeł. J. Kydryński, w: tegoż Cztery opowiadania. List do ojca, przeł. J. Kydryński, J. Ziółkowski, Warszawa 2003, s. 88.

19 Tamże, s. 89. 
przypieczętuje los Gregora jako nie-człowieka. Sebaldowski narrator także przykrywa własnym ciałem obraz, tyle że tutaj obrazem jest okno. Kieruje nim - podobnie jak Samsą - strach, lecz w odróżnieniu od Samsy strach polegający na świadomości, że za oknem nic nie ma, a raczej, że jedynie okno (obraz) jest tym, co jest; stanowi wyraz podskórnego lęku narratora przed reprezentacją, na podobnej zasadzie co Indianie boją się robienia zdjęć. Choć może obydwoma bohaterami kierowało ta samo, potrzeba zakotwiczenia się w rzeczywistości poprzez jej obraz, w końcu Sebaldowski narrator, wstając z łóżka do okna, co - podobnie jak Gregora - wiele go kosztuje fizycznie, w pewnym sensie musi to zrobić, by utwierdzić się w swojej podmiotowości (i cielesności) poprzez zespolenie się z obrazem.

Wyjrzenie przez okno wywołuje u niego zjawisko, które nazywać będę „efektem dwu-widzenia"20.

Nie mogłem sobie wyobrazić, by tam w dole, wśród bezładnie zazębiających się murów, coś się jeszcze poruszało, i byłem przekonany, że spoglądam z wysokiej skały na kamienne morze albo żwirowisko, z którego niczym kolosalne głazy narzutowe sterczą posępne bloki wielokondygnacyjnych parkingów. ${ }^{21}$

Podobnie jak w obrazach Francisa Bacona, gdzie jako widzowie jesteśmy zmuszeni wejść w środek obrazu ${ }^{22}$, w pewnym sensie zakryć go, zjednać się $\mathrm{z}$ nim. U Bacona proces ten ma na celu otworzenie naszej percepcji na obraz, u Sebalda raczej na zamknięciu jej. W pierwszym wypadku obraz wciąga oglądającego, w drugim to oglądający wciąga obraz.

Narrator równocześnie widzi dwa wykluczające się krajobrazy: przyrodę i miasto ${ }^{23}$. Oba obrazy nakładają się na siebie, jak źle wywołane zdjęcie ${ }^{24}$.

Koncepcja ta na wielu poziomach łączy się z teorią „rozdwojonego wyobrażenia” Victora Stoichity. Zob. V.I. Stoichita Ustanowienie obrazu, s. 15-28.

W.G. Sebald, Pierścienie Saturna, s. 9.

Poprzez wystawianie ich za szkłem, co powoduje, że oglądający odbija się w nich.

Istotne wydaje się, że Sebald wybrał akurat wizję skał wystających z morza, gdyż właśnie takie samo zdjęcie, autorstwa Timothy O'Sullivana opisuje Krauss w swoim eseju o fotografii.

Zupełnie inne (ze względu na antyfiguratywność), aczkolwiek zbieżne w założeniach podejście zastosował w 1992 roku na Documenta IX Gerhard Richter w instalacji składającej się z serii szarych obrazów. Płótna pokryte były w całości szarą farbą i wystawiane za szybami, co powodowało, że zamieniały się w lustra. 
W tym sensie okno, które stanowi punkt wyjścia dla dwu-widzenia narratora w warstwie narracyjnej, jako fizyczne zdjęcie w samej książce zamienia się w ekran, na który jako czytelnicy projektujemy zarówno dwu-widzenie bohatera, jak i nasze własne doświadczenie czytania/oglądania powieści (naszą narrację percepcji).

Annibale Carracci dla rozbawienia gości na przyjęciach często tworzył zagadki wizualne, które polegały na rysowaniu kilku linii lub kształtów przedstawiających (maskujących) coś bardzo skomplikowanego ${ }^{25}$. Goście mieli za zadanie zgadnąć, co jest przedstawione. Zagadki te były pułapkami, gdyż nie sposób było zidentyfikować tego, co narysowane, bez klucza, bez legendy. Jeden z rysunków np. przedstawia murarza z gładzikiem formierskim, stojącego za murem, który kładzie zaprawę murarską pod kolejną warstwę cegieł; inny kardynała siedzącego na pulpicie, wsłuchanego w kazanie lub ślepca wyłaniającego się zza winkla, z puszką na jałmużnę i laską. Tak to ma „wyglądać”, lecz jako widzowie dostajemy tylko szkielet, kilka kresek tworzących geometryczne kształty, które nie przypominają nic, a już na pewno nie kardynała, murarza i ślepca. Bez klucza (opisu) widzimy tylko nic nieznaczące kreski, dopiero po objaśnieniu "dopełniamy” nasze widzenie znaczeniem, poprzez swoisty rodzaj konceptualizacji wizualnej, efekt dwu-widzenia. Nagle „widzimy historię". W tym sensie obraz otwiera się, umożliwiając nam nie tylko identyfikację śladu wizualnego z jego denotacją, ale również „ujrzenie” całej narracji wizualnej de facto nieobecnej bezpośrednio w samym przedstawieniu (interwizualność). Narracja, która polega na „konceptualizacji”, nie jest wyrażalna, możemy ją jedynie „odczuć”, niejako post factum w procesie analizy naszej percepcji. W rzeczywistości obrazy te nie istnieją.

Według Mieke Bal, każdy rodzaj percepcji jest w gruncie rzeczy halucynacyjny, gdyż nie posiada przedmiotu, jest jedynie (aż?) konstruktem podmiotu, który jest równocześnie zarówno źródłem, jak i celem percepcji. Przekładając to na teorie narratologiczne Bal formułuje tezę, że fabuła, zanim zostanie w pełni wyjawiona czytelnikowi, istnieje w zarysie, w sposobie "pokazywania” świata przez opisy narratora lub bohaterów, czyli w swego rodzaju intuicyjnej „wizji fabuły"26. Relację między elementami przedstawionymi i sposobem ich

Zob. C.C. Malvasia Felsina Pittrice, Bologna 1678, za: R. Wittkower Interpretation of Visual Symbols, w: tegoż Allegory and Migration of Symbols, Thames and Hudson, New York 1987, s. 177. 
widzenia lub wizją, poprzez którą elementy te są dane odbiorcy, konstytuuje fokalizacja. Jest to, można by rzec, „aparatura”, przez którą widzimy świat, tyle że świat ten jest fikcyjny i eo ipso budowany jedynie „w widzenia”. Elementy te są zależne od siebie, nie możemy zmienić „aparatury” bez równoczesnej zmiany świata. Opisy Carracciego byłby niepełne bez piktogramów i na odwrót. Porównać to można do mikroskopu i lunety: choć pozornie poprzez oba te narzędzia widzimy świat zewnętrzny, jest to kompletnie inny świat i tylko racjonalizm podpowiada nam, że jest to ten sam świat tylko przedstawiony w różnych stopniach oddalenia.

Tymczasem w szpitalu w Norwich Sebaldowski narrator przechodzi od okna, do rozważań nad życiem i twórczością Thomasa Browne'a, który „traktował nasz świat tylko jako cień innego świata”. Według Sebalda Browne, starał się patrzeć na ziemski byt „okiem stwórcy”, aby to osiągnąć używał „niebezpiecznej lotności języka”. Fokalizacja jest formą demiurgi, obrazy, które fokalizator tworzy, są dla czytelnika rodzajem kotwic i, jak każda kotwica, mogą go albo utrzymać u brzegu, albo pociągnąć na dno.

Wprawdzie nie zawsze, między innymi z powodu tego kolosalnego obciążenia, udaje mu się oderwać od ziemi, ale gdy już wraz z ładunkiem wzbija się obrotami prozy coraz wyżej i wyżej, jak szybownik niesiony ciepłymi prądami powietrza, wtedy nawet dzisiejszego czytelnika ogarnia uczucie lewitacji. Im bardziej rośnie oddalenie, tym jaśniej widać. Z największą dokładnością dostrzega się najdrobniejsze detale. Tak jakby się patrzyło przez odwróconą lunetę i przez mikroskop jednocześnie. ${ }^{27}$

Michel Foucault w To nie jest fajka analizuje sławny obraz Magritte'a nie, jak tradycyjnie się go ujmuje, w kontekście niemożliwości uchwycenia równocześnie tego, co widzimy i tego, co czytamy, lub ontologii obrazu, lecz kaligramu. Dla niego bowiem zarówno słowa są obrazem, jak i obraz jest słowami:

osobliwość tej ilustracji nie wynika ze „sprzeczności” między obrazem a tekstem. Z prostego powodu: sprzeczność pojawia się tylko między dwiema wypowiedziami albo w obrębie jednej i tej samej wypowiedzi. Tu natomiast nie ma wątpliwości, że jest to jedna wypowiedź, która na dodatek nie może być sprzeczna, bo tematem zdania jest proste 
oznajmienie. Czy tylko dlatego fałszywe, że „referent” - bez wątpienia fajka - go nie potwierdza?28

Niemniej pisze o „zburzonym kaligramie”. Dlaczego?

Kaligram zażegnuje nieprzezwyciężalną nieobecność, której słowa same nigdy nie są w stanie zaradzić, narzucając im podstępnie, dzięki rozwijającemu się w przestrzeni pismu, widzialną formę ich referencji [... $]^{29}$

Widz czyta, a czytelnik widzi. Czy to będzie podobieństwo? Na pewno nie jest to fajka. Między tym, co wypowiadalne, a tym, co przedstawialne, powstaje trzeci wymiar. Obrazy i słowa stają się niewypowiadalne, choć zrozumiałe, jak "szibbolet" dla Efraimitów. Słowa odklejają się od swoich desygnatów, a desygnaty od swoich konotacji, kluczowe "sz" identyfikacji umożliwiające przejście na drugi, bezpieczny brzeg (rozumienie) ulatnia się. Punkt łączący znaczenie z obrazem rozrywa pustka, która wbrew ontologii zaczyna bytować, choć nadal zgodnie z logiką nie sposób ją wyartykułować. Opisywanie obrazu tworzy pustkę. Tylko za cenę własnego zniknięcia, obraz może stać się dostępnym przedmiotem, który można opisać i zinterpretować. To zaś zakłada, że nigdy nie mamy dostępu do jego pierwotnych uwarunkowań. Powróćmy jednak do przysłowiowej fajki, która nią nie jest. Foucault pisze, że słowa w tym obrazie są zaledwie refleksami słów, nie istnieją w swojej dyskursywnej funkcji, tylko przyjmują funkcje obrazu (wizualizują), co z kolei prowadzi do tego, że język i obraz mieszają się, wzajemnie przesłaniają. Jako widzowie możemy tylko albo czytać i nie widzieć, co jest niemożliwe; albo widzieć i nie czytać (np. nie rozumieć, ponieważ nie znamy francuskiego). To z kolei powoduje, że napis (opis) może jedynie spełniać funkcję sensu stricto dekoracyjną. Gdy zaczniemy rozumieć, co jest napisane, figura fajki jakby się rozprasza, traci swoją bytowość, ale tylko chwilowo. Poprzez tę negację (rozumianą przez Foucaulta na wielu poziomach $^{30}$ ) widzeniu zostaje odebrane znaczenie i na odwrót:

Cieniutka granica, bezbarwna i niewidoczna, która na rysunku Magritte'a rozdziela tekst i obrazek, tak oto ukazuje się wyrwą, ciemnym lasem

M. Foucault To nie jest fajka, przeł. T. Komendant, Gdańsk 1996, s. 13. 
i pustynną dziczą, oddzielającą teraz fajkę bujającą w niebie obrazu od słów, które pokornie drepczą zgodnie z ziemskim porządkiem następstwa. Pustka czy luka - to nawet za mało powiedziane: to raczej brak wspólnej przestrzeni, likwidacja loci communis dla znaków pisma i linii obrazu. „Fajka”, nie dająca się dotychczas podzielić na nazywającą ją wypowiedź i mający ją przedstawiać rysunek, ta zjawiskowa fajka, pozwalająca przeplatać kreski kształtu z muskułami słów, definitywnie się ulatnia. Po przejściu tego płytkiego strumyka, na drugim brzegu, o tym zaniku tekst zresztą zabawnie mówi: to nie jest fajka. Samotny odtąd rysunek fajki na próżno będzie udawał, że przypomina coś, co zwykle określa się słowem „fajka”; na próżno tekst mościć się będzie pod rysunkiem na kształt i podobieństwo czułej legendy w uczonej książce; między nimi zaistnieć może już tylko pozew rozwodowy i wypowiedź, która przeczyć będzie zarazem nazwie rysunku i referencji tekstu. Nigdzie nie ma fajki. ${ }^{31}$

Przez moment doświadczenie rozumienia i widzenia przechodzi w trzeci wymiar, w nieobecność, czyli w niewypowiadalne doświadczenie śmierci, która tak naprawdę jest tematem dzieła Magritte’a i rolą obrazów w powieści Sebalda, jeśli nie obrazów w ogóle. Dlatego Pierścienie Saturna na metapoziomie stanowią traktat o widzeniu w literaturze. Jako czytelnicy stajemy wewnątrz obrazu.

\section{Szibbolet}

Znajdźmy się teraz gdzie indziej. Linia brzegowa, trzy - cztery mile na południe od Lowestoft „zakreśla szeroki, lekko wygięty w głąb lądu łuk”. Taką wizją rozpoczyna się trzeci, kluczowy dla Pierścieni Saturna, rozdział. Użyłem terminu „wizja”, gdyż fragment ten zawiera zarówno opis plaży, jak i jej zdjęcie. Czy to będzie fajka? Według opisu i obrazu na plaży stoją szałasy. „Ciągną się wzdłuż morza długim szeregiem i w dość regularnych odstępach"32. Widzicie to? Spójrzcie na zdjęcie. Czy podwójne „widzenie” jest niezbędne, by tę plażę dostatecznie „zobaczyć”? Czy nie wystarczy albo opis, albo zdjęcie? Po co oba? Czy opis plaży jest tym samym, co jej zdjęcie? Magritte słowem zanegował fajkę, którą mieliśmy przed przysłowiowymi oczami, Sebald wydaje się ją potwierdzać. Ale czy rzeczywiście? Czy poprzez równoczesną narrację

Tamże, s. 25-26. 
słowną i obrazową plaża nie staje się fantomem na podobnej zasadzie, co fajka w opisie Foucaulta, która się rozprasza? A może odwrotnie, to opis zostaje wchłonięty przez obraz i działa jedynie na zasadzie echa? W czwartym zdaniu Sebald uruchamia (dopełnia) obraz, dodając do niego coś, czego nie ma na samym zdjęciu:

Tak jak gdyby tu, na krańcu ziemi, osiedlili się ostatni przedstawiciele jakiegoś wędrownego plemienia w oczekiwaniu z dawna wyglądanego cudu, usprawiedliwiającego ex post wszystkie przebyte trudy i błąkania. ${ }^{33}$

Zdjęcie się zmienia, choć pozostaje takie samo, na moment wkraczamy w inny wymiar, pośrednio uczestniczymy w tym, co niewyrażalne. Sebald jednak nie na długo pozwala nam przebywać w tym innym świecie, szybciutko zmazuje wędrowne plemię i wprowadza rzeczową legendę do zdjęcia:

W rzeczywistości jednak ci, którzy obozują tu pod gołym niebem, nie zdążali na wybrzeże przez dalekie kraje i pustynie, są to bowiem ludzie z najbliższej okolicy, którzy starym zwyczajem z wędkarskich stanowisk obserwują nieustannie zmieniające się przed ich oczami morze. ${ }^{34}$

To nie jest plemię. Brak przybyszy z odległych krain na plaży, wyczekujących cudu, w który i my także już zaczęliśmy wierzyć (a przede wszystkim widzieć), powoduje, że ich chwilowa obecność staje się tym bardziej bolesna, ponieważ ich już nie ma, wyjechali. Plaża na zdjęciu pustoszeje jeszcze bardziej.

W momencie czytania opisu sam bohater powieści znajduje się w miejscu, o którym czytamy, czyli widzi to, co my, lub raczej my widzimy to, co on. Widzimy przez jego widzenie lub raczej widzimy to, czego on nie widzi. Fragment ten staje się przestrzenią, której nie ma jak okno/sztaluga Magritte'a. Ale wróćmy na plaże w Lowestoft. Czy nie jest tak, że zdjęcie przeszkadza nam w opisie? Stanowi nieustanne przypomnienie tego, że nie jest tak jak czytamy, że to, co przeżywamy, to, co „widzimy”, czytając, nie istnieje. Jest kotwicą, która nie pozwala nam się ruszyć, czyniąc wszystkie wizje pochodzące z tego opisu czymś nierealnym. Obraz staje się pustką (a może jest przezroczysty, jak duchy w filmach, co czyni je jeszcze bardziej nieobecnymi bo prawie widzialnymi, prawie posiadającymi substancję, jak lekko zamazana 
szyba w oknie, jak fantom). Zdjęcie plaży przekształca opis plaży w krainę śmierci (podobnie jak reszta zdjęć w powieści przekształca pielgrzymkę narratora w drogę w nicość) ${ }^{35}$. Zostajemy wessani w świat, którym rządzi brak, gdzie desygnaty zniknęły lub nigdy ich nie było, wszystko podlega prawom nieobecności, otaczają nas duchy. Jesteśmy w świecie nieżywych i w żaden sposób nie możemy się tam uobecnić, opisać tego, co widzimy, ponieważ tak naprawdę nic nie widzimy, bo nas tam po prostu nie ma. Narratora zresztą też. Nic nie rozświetli tej ciemności.

Zagadka szibboleta łączy się z zagadką przekładu. W tekście poświęconym Paulowi Celanowi Derrida przywołuje koncepcję szibboleta jako przykładu doświadczenia "niepowtarzalnego" (unwiederholbar), leżącego u źródeł poezji tego twórcy i, wydaje się, poezji w ogóle.

Będę więc mówił zarazem o obrzezaniu i o jedynym razie, innymi słowy, o tym, co powraca aby zaznaczyć jako jedyny raz: o tym, co czasem nazywa się datą. ${ }^{36}$

Derrida stosuje figurę obrzezania jako metaforę daty. Obrzezanie jako data zdarza się tylko jeden raz, ale czym jest ten „jeden raz"? Przede wszystkim obrzezanie cechuje jednostkowość i ostateczność, jest to pierwszy i ostatni raz, co z kolei wpisuje je w ogniskową archeologii i eschatologii. Jest to miejsce przecięcia (sic!) między tym, co było, a tym, co nigdy już nie będzie. W tym sensie zasada podobieństwa nie istnieje. To nie jest fajka bo „niemożliwe jest powtórzenie”. Należy poprawnie wymówić „szibbolet”, aby mieć prawo przejścia, prawo do życia, tylko poprawne wymówienie tego słowa jest niemożliwe, bowiem kluczowe „sz” jest nie do wyartykułowania. Obrazy w powieści Sebalda przenikają opisy, opisy przenikają obrazy, obecność staje się nieobecnością; każde zdarzenie, każda historia, wspomnienie, wizja, szuka swojego „sz", szuka miejsca pojednania, powrotu do domu, ale powroty nie istnieją. Nawet te najbardziej banalne odwiedziny za każdym razem są czymś innym.

Pod postacią jedynego pierścienia ze swojej konstelacji, jedna i „ta sama” data upamiętnia różnorakie zdarzenia, jedno, sąsiadujące nagle z drugim,

35 Fotografia plaży przypomina zdjęcie Rogera Fentona The Valley of the Shadow of Death stanowiące punkt wyjścia dla rozważań Susan Sontag na temat śmierci, która jest wpisana w ideę obrazu. Zob. S. Sontag Widok cudzego cierpienia, przeł. S. Magala, Kraków 2010, s. 35.

36 J. Derrida Szibbolet dla Paula Celana, przeł. A Dziadek, FA-art., Bytom 2000, s. 5. 
nawet jeśli wiadomo, że są one i muszą pozostać nieskończenie sobie obce. To właśnie nazywa się spotkaniem, spotkaniem innego, „tajemnicą spotkania", a ściślej mówiąc - odkryciem Południka. ${ }^{37}$

Obrzezaniem w tym kontekście będzie również krajobraz, jako forma uobrazowienia natury i tym samym uniemożliwienie powrotu do niej (do tego samego miejsca w przestrzeni), bo zawsze już będzie ono inne lub „tylko obrazem”., „Szibbolet pozostaje tajemnicą, niepewnym przejściem”38. Obraz, ten dosłowny obraz, staje się szibboletem, za sprawą którego nie możemy dostać się na drugi brzeg. Za sprawą, którego czeka nas zagłada. Zostajemy uwięzieni w pierścieniach Saturna.

Reszta psuła się w ciągu kilku dni i przedstawiała straszliwy obraz natury dławiącej się własnym nadmiarem. ${ }^{39}$

\section{Gdzie leży śmierć?}

Ósmego grudnia 2000 roku uzbrojony zbieg z więzienia włamuje się na teren farmy amerykańskiej artystki Sally Mann. Wkrótce zjawia się policja i po nieudanej interwencji, strzela do niego, zabijając na miejscu. Po kilku godzinach, gdy trup zostaje już zabrany, a policja odjeżdża, Mann udała się w miejsce, gdzie jeszcze przed chwilą leżało ciało zabitego. Na początku nie zauważa niczego wyjątkowego, dopiero gdy dokładniej przygląda się miejscu śmierci „pod samotnym drzewem orzesznika”, spostrzega małą błyszczącą kałużę krwi. „Była tak ciemna, że przypominała roztopioną czekoladę"40. Gdy próbuje jej dotknąć, kierowana - jak sama przyznaje - makabryczną ciekawością, kałuża zaczyna drgać i momentalnie zostaje wchłonięta przez ziemię. „Śmierć pozostawiła swoje niezbywalne znamię w zwykłym zagajniku drzew, na moim podwórku. Ale czy nieznajomy przybysz, wędrujący przez ten teren za sto lat, byłby w stanie wyczuć świętość tej skażonej śmiercią ziemi?"41.

Tamże, s. 14 .

Tamże, s. 30.

W.G. Sebald Pierścienie Saturna, s. 66.

Fragment filmu dokumentalnego Stevena Cantora What Remains: The Life and Work of Sally Mann (2005).

S. Mann What Remains, przekł. wł., Bullfinch Press, New York 2003, s. 72. 
Gdzie leży śmierć? Wydaje się pytać Sally Mann poprzez swoje fotografie - obrazy natury, krajobrazów, które stały się miejscami zabójstw. To samo pytanie, choć mniej bezpośrednio, poprzez słowa i wędrówki (pielgrzymki), zadaje Sebald. Czy topografia jest istotna? Czy w ogóle chodzi o topografię? Tak i nie. Krajobraz stanowi nieodłączny element doświadczenia śmierci u obu artystów, zarówno ten dosłowny, jak i ten mniej dosłowny. Poprzez widzenie topograficzne próbują oni nazwać to, co nie nazwane, wypowiedzieć to, co nie wypowiadalne. Próbują wyartykułować szibbolet.

Gdy ziemia włącza zmarłych do siebie stają się częścią jej bogatego ciała, ciemną materią stworzenia. Przechadzając się po polach, na tej farmie, pod moimi stopami przesuwają się kości niezliczonych ciał; śmierć jest rzeźbiarzem tego zachwycającego krajobrazu, jego straszliwą matką, wilgotnym stwórcą życia, przez które pewnego dnia i my zostaniemy pożarci. ${ }^{42}$

Wróćmy jeszcze raz na plażę w Lowestoft, a raczej wypłyńmy na połów śledzia. Sebald opis połowu zaczyna od wskazówki, co do sensu całego rozdziału: „Nie na darmo śledź był zawsze szczególnie popularnym obiektem dydaktycznym w niższych klasach, jako symbol zasadniczo niespożytych sił witalnych natury" ${ }^{\prime 3}$. Sebald chce nas czegoś nauczyć. Następnie przechodzi do opisu filmu, który widział w szkole, gdzie „widać” kuter z Wilhelmshaven, który łowi śledzie w nocy, a przynajmniej tak się wydaje narratorowi. Ważne w tym fragmencie jest to, że narrator nie widzi połowu śledzi, tylko relacjonuje film, który widział w przeszłości ${ }^{44}$. Ale narrator nie widzi też samego filmu, tylko wspomnienia z niego.

A czymże byłyby obrazy? Tym, co raz, zawsze od nowa raz, tylko tu i teraz doznane i doznawane. A wiersz byłby tym punktem, w którym wszystkie tropy i metafory chcą, aby doprowadzić je ad absurdum. ${ }^{45}$

Tamże, s. 6. W.G. Sebald, Pierścienie Saturna, s. 64. Ciekawy jest ten opis pod względem fokalizy, szczególnie sformułowań stosowanych przez narratora, np.: "we wspomnieniach z tego filmu widzę".

45 P. Celan Meridian. Przemówienie wygłoszone z okazji przyznania nagrody im. G. Büchnera, wyb. i oprac. R. Krynicki, Kraków 1998, s. 337. 
Film z połowu śledzi zamienia się w zdjęcie rybaków stojących nad górą, dopiero co złowionych ryb. Obraz ten (poprzez obszerny i wyczerpujący opis historii i sposobu łowienia śledzi) zostaje z nami. Jest rodzajem daty w naszym czytaniu, zakładką narracji. Przechodząc (jako czytelnicy i widzowie) wraz z narratorem poprzez opis budowy anatomicznej śledzia, tradycji związanych z jego wykorzystaniem, nieoczekiwanie wchodzimy w zdjęcie „projektu totalnej iluminacji naszych miast", by na koniec znaleźć się w Auschwitz. Zdjęcie stosów ofiar, leżących w lesie, niepokojąco przypomina górę śledzi, jego łuski i iluminacje z poprzednich zdjęć. Sebald zostawia nas z tym zdjęciem bez komentarza. Jakby bał się je (na)poruszyć. Cała poprzednia narracja, zarówno ta słowna, jak i wizualna, prowadzi nas właśnie do tego miejsca. Jako jedno z czterech zdjęć w powieści wydrukowane jest dwustronnie. Pozostałe trzy to (w porządku chronologicznym fabuły powieści) zdjęcie fragmentu dziennika Rogera Casementa ${ }^{46}$, zrobione od środka zdjęcie kolumn w makiecie Świątyni Jerozolimskiej Aleca Garrarda i fragment ksiąg XIX-wiecznych rejestrujących wpływy z jedwabnictwa w Prusach. Wszystkie cztery układają się w pewien ciąg narracyjny (podobnie jak wcześniej w mikrociąg składały się zdjęcia plaży, śledzia i iluminacji), który stanowi klucz do zrozumienia całej powieści, do wypełnienia narracji słownej (opis) narracją wizualną (obraz). Budują interwizualność całej powieści. Ustanawiają quincunx, którym fascynował się Browne ${ }^{47}$, od którego (i kawałka nieba w oknie) zaczyna się cała fabuła. Ale ich znaczenie jest niezrozumiałe, a raczej niewypowiadalne. Stanowią szyfr: Holokaust, kolonializm, Jerozolima, jedwab. Jeżeli cała powieść, interakcje obrazu i słowa (w kontekście interwizualności) tworzy szibbolet, te cztery obrazy są jego „sz". Każde ze zdjęć (dwa z nich dosłownie) są obrazem języka. Tworzą zatem „zburzony kaligram”. To nie jest fajka, to coś znacznie straszniejszego.

Sebald stara się stworzyć tekst absolutny, ale takowy nie istnieje. Zdjęcia w powieści pełnią funkcję dat, są szibboletami. Tyle że wpisanie daty nie jest tylko oznaczeniem roku, momentu, fragmentu życia, ale też miejsca, tym

46 Zob. M.V. Llosa Marzenie Celta, przeł. M. Chrobak, Kraków 2011.

47 „Browne odkrywa tę strukturę wszędzie, w żywej i martwej materii, w pewnych formacjach krystalicznych, u rozgwiazd i jeżowców, w stosie pacierzowym ptaków i ryb, na skórze wielu gatunków węży, w śladach stąpających na krzyż czworonogów, w układzie ciał gąsienic, motyli, jedwabników i ciem, w korzeniach paproci wodnych, w łupinkach nasion słonecznika i pinii, w przekroju młodych pędów dębu, w łodygach skrzypu i w dziełach rąk ludzkich, w egipskich piramidach, w mauzoleum Augusta, tak samo jak w obsadzonym pod sznurek drzewkami granatu i białymi liliami ogrodzie króla Salomona", W.G. Sebald Pierścienie Saturna, s. 27-8. 
samym zatarcia go. Data „musi zatrzeć, aby mogła stać się czytelną, stać się nieczytelną w samej swej czytelności" ${ }^{\prime 48}$. Data jest widmem, nigdy nie powróci lub zawsze będzie powracać tylko w sobie, zapętlona niczym linie papilarne, które z jednej strony stanowią o naszym indywidualizmie, lecz z drugiej ich forma cylindryczna wyraża nieskończoną powtarzalność. Podobnie jak obrazy, jak zdjęcia w Pierścieniach Saturna.

Wówczas Jefte zebrał wszystkich mężów z Gileadu i rozpoczął walkę z Efraimitami. Mężowie z Gileadu pokonali Efraimitów, gdyż ci mówili: „Jesteście zbiegami z Efraima, o Gileadczycy, którzy przebywacie wśród Efraimitów i Manassytów". Następnie Gileadczycy odcięli Efraimitom drogę do brodów Jordanu, a gdy zbiegowie z Efraima mówili: „Pozwól mi przejść”, Gileadczycy zadawali pytanie: „Czy jesteś Efraimitą?” - A kiedy odpowiadał: „Nie”, wówczas nakazywali mu: „Wymówże więc Szibbolet”. Jeśli rzekł: Sibbolet - a inaczej nie mógł wymówić - chwytali go i zabijali u brodu Jordanu. Tak zginęło przy tej sposobności czterdzieści dwa tysiące Efraimitów. ${ }^{49}$

48 J. Derrida Szibbolet dla Paula Celana, s. 18.

49 Biblia Tysiąclecia, Księga Sędziów, 12,4-7. 


\section{Abstract}

\section{Radosław Filip Muniak}

UNIVERSITY OF SOCIAL SCIENCES AND HUMANITIES (WROCŁAW)

The Image as a Shibboleth: W.G. Sebald's The Rings of Saturn

Muniak examines the metaphysics of the image in W.G. Sebald's The Rings of Saturn. His focus is on the role of photographs and what constitutes their meaning in the novel's narrative layer and in the notion of the image in general. The point of departure is the figure of the window as an image that cannot be transgressed (a shibboleth), its metaphysical and hermeneutic connotations as well as its meaning in the context of a broadly understood philosophy of culture.

\section{Keywords}

metaphysics, image, narrative, window, philosophy of culture, Derrida, Sebald, Foucault, art, seeing, Bal, Magritte 